\title{
Government suspends new mining projects
}

\section{Canberra}

THE Australian Government is in two minds on the thorny question of whether or not it should continue to mine and export uranium. It has given the go-ahead for one new mine, at Roxby Downs in South Australia, where gold and copper will be mined together with uranium, which is consistent with Labor Party policy. But that policy also commits the government to phase out the uranium industry, although the Prime Minister, Mr Bob Hawke, together with some members of his cabinet, believes in what is called "sequential development". The result is that eleven other mining proposals, and new contracts on all but one existing mine (Ranger), are in abeyance pending the outcome of a government inquiry to be carried out into Australia's role in the nuclear fuel cycle.

Mr Lionel Bowen, Minister for Trade, says the decision to call a halt to new uranium mining has been taken on economic grounds, because the market cannot sustain new uranium mines. After the federal caucus decision last month, he pointed out in the House of Representatives that 100,000 tonnes of uranium held on the Ranger and Nabarlek mines in the Northern Territory are unsold. There is no processing of uranium apart from its conversion to yellowcake before export, and Australia does not have an indigenous nuclear power industry. In addition, the export of uranium to other countries is subject to bilateral agreements. Australia has negotiated ten uranium treaties, which may limit, for instance, the transfer of nuclear material to a third country.

The federal caucus, essentially the Labor Party's parliamentary policy-making body, has also decided that Australia should review its bilateral agreements so as to strengthen safeguards against reprocessing, against the diversion of nuclear material to countries that have not signed the Non-Proliferation Treaty and against the fabrication of nuclear weapons. It will also examine further opportunities for suppliers of uranium to "advance the cause of nuclear non-proliferation having regard to the policies and practices of recipient countries", and ways in which it can contribute to the safe disposal of nuclear waste.

This may give an impetus to the Synroc project now being developed at the Australian Atomic Energy Commission for the immobilization of high-level wastes from a power reactor. Ironically, in view of the fact that the government has just abolished the Uranium Advisory Council, the caucus recommended the establishment of a commission to consider the "full range of issues relating to the nuclear fuel cycle",.

The study of bilateral agreements and of Australia's role in nuclear non-proliferation and in the safe disposal of highlevel wastes has been referred to the Australian Science and Technology Council (ASTEC), an advisory body that reports directly to the Prime Minister. The new chairman of the council is Professor Ralph Slatyer.

That decision is a reaffirmation for the first time since this government took office of the council's importance in decision- making. ASTEC was chosen to carry out the review because it is the body least likely to be accused of bias, but it was nevertheless reluctant to grasp the uranium nettle. Whatever the report says, it is likely to be controversial, and the council's policy of seeking consensus is unlikely to be feasible in this instance.

Many questions hang on the outcome of the inquiry. The present suspension of uranium contracts with France may be reviewed, new contracts for existing mines may be re-examined and conditions for the export of uranium from the Ranger mine to US utilities defined. Most important of all, the Prime Minister, armed with the report, may be able to tell delegates at the Australian Labor Party conference in July next year that the export of uranium is after all not only safe but good for the country.

Vimala Sarma

\section{Heidelberg grows bigger centre}

THE concentration of biomedical institutions at Heidelberg in West Germany continues to grow. The university biology department, now uncomfortably crowded into a single block, will acquire a new institute for molecular biology in 1984. This was started with a grant of DM1 million (E0.25 million) a year from the giant chemical concern BASF. Last week, the company announced that the grant would be extended for a total of ten years.

The federal government will also contribute DM3.5 million a year for five years and the Land of Baden-Wurtemberg DM30 million for construction. The BASF money is crucial to the success of the venture, since it gives the institute freedom to compete in the open market for senior scientists by not being bound by the restrictions that impede the mobility of employment in German universities, making it difficult for them to respond to changes in developing fields by hiring non-tenured staff members.

The twin roles of the new institute are basic research and training. BASF will not be entitled to patents or patent licences but instead to staff training. It is also hoped that the institute will help to meet the present shortage of trained biotechnologists in the federal republic.

The new rector at the University of Heidelberg is keen on the development. Professor Giesbert zu Putlitz returned to Heidelberg in October after five years as director of the Heavy Ion Research Institute at Darmstadt, and although himself a professor of physics at Heidelberg, he is well acquainted with biotechnology through his experience as chairman of the National Committee of the Large Research Institutes, which include the institutions at Jülich and Braunschweig.

Dr zu Putlitz would like to see stronger links with industry, but suggests that the institute's main role would be basic research, with final steps towards commercial processes being made in the industrial laboratories. He is chairman of one of the institute's governing bodies and involved in its international scientific advisory board.

A further development at Heidelberg is the formation of a small biotechnology company, Progen Biotechnik, which it is hoped will begin producing antibodybased diagnostic kits and recombinant DNA products in the Heidelberg science park next year. The founders are four senior Heidelberg molecular biologists. Although modest by US standards, the project, which aims at an initial capitalization of DM13 million, is something of an innovation in West Germany and its prospects are by no means clear.

The German business environment discourages venture capital, the source of capital for most start-up companies in the United States. While the business community frequently deplores these restrictions and the federal government is committed to policies favouring their development in West Germany, the legal and financial obstacles may yet prove insurmountable. If Progen Biotechnik gets off the ground, it will be a sign of healthy relaxation.

These new developments give Heidelberg a noticeable edge over other West German centres in biotechnology. The city already provides quarters for the European Molecular Biology Laboratory and for the German Cancer Research Centre, the much troubled national research laboratory with a staff of more than 1,000 , now settling down under its new director, Professor G. zu Hausen, who transferred from Freiburg at the beginning of the year.

Apart from the academic departments at the university, Heidelberg also has the Max-Planck institute for medicinal chemistry, a fruitful field for head-hunters in the recent past.

Sarah Tooze 